\title{
APPLICATION OF THE ENERGY EFFICIENT HEATING SYSTEM OF THE POULTRY HOUSE
}

\author{
N. A. Spodyniuk, PhD, Assistant Professor \\ National University of Life and Environmental Sciences of Ukraine
}

E-mail:n_spoduniuk@meta.ua

\begin{abstract}
The share of thermal energy in the total energy balance of rural areas is about $90 \%$. A considerable amount of it is spent on the heat supply of the premises of livestock complexes. For example, breeding poultry under industrial conditions is characterized by a large concentration of poultry on the premises and involves the creation of bulky poultry complexes. This necessitates compliance with the special requirements for ensuring the required temperature regime in order to obtain high productivity of poultry at lower specific feed costs per unit of production. Due to poor temperature parameters in the poultry house, the potential productivity of the poultry is only 20-30\% of the total productivity. There is an increase in metabolism, accompanied by an increase in feed costs. When breeding poultry meat breeds the deviation of the air temperature from the required value by only one degree leads to a marked decrease in the productivity of the poultry. Therefore, the task of modern systems of heat supply of poultry premises is to maintain the necessary temperature parameters in the location of poultry with quality control of air temperature as the poultry grows, which will significantly reduce energy consumption. The design of a local heating system, which is able to provide the necessary zoo hygienic requirements in the location of the poultry and a new way of growing poultry - modular poultry farming was proposed. With this method of keeping the poultry, the specified temperature conditions are created and a certain microclimate is required to ensure the zoo hygienic requirements with possible efficient and economical use of energy resources during economically justified period of normal operation. The paper justifies the feasibility of using energy-efficient technologies based on infrared radiation. Efficiency of application of the module for growing poultry with infrared radiator and forced ventilation system was confirmed. The field of influence of the exhaust outlet was studied and investigated under field conditions. It is established that the outlet operation does not affect the overall distribution of air flow in the module, since the radius of the suction torch is $0.16 \mathrm{~m}$ with a maximum exhaust air flow rate of $880 \mathrm{~m}^{3} / \mathrm{h}$. Based on studies conducted on the efficiency of the exhaust outlet, it is found that the amount of heat recovered from the exhaust air is 30\% of the heat output of the infrared heater.
\end{abstract}

Key words: infrared heater, exhaust outlet, suction torch, module for poultry breeding. 
Actuality. One of the important issues in Europe's energy policy is the economical use of energy to support technological processes in various industrial and agricultural sectors. European Commission provides data on active growth in agricultural consumption, which in turn leads to an increase in funds of maintaining the agro-industrial complex [1]. As a result, there is a need for rational provision of energy resources for agro-industrial facilities, in particular poultry houses, including poultry when breeding poultry for meat (fig.1).

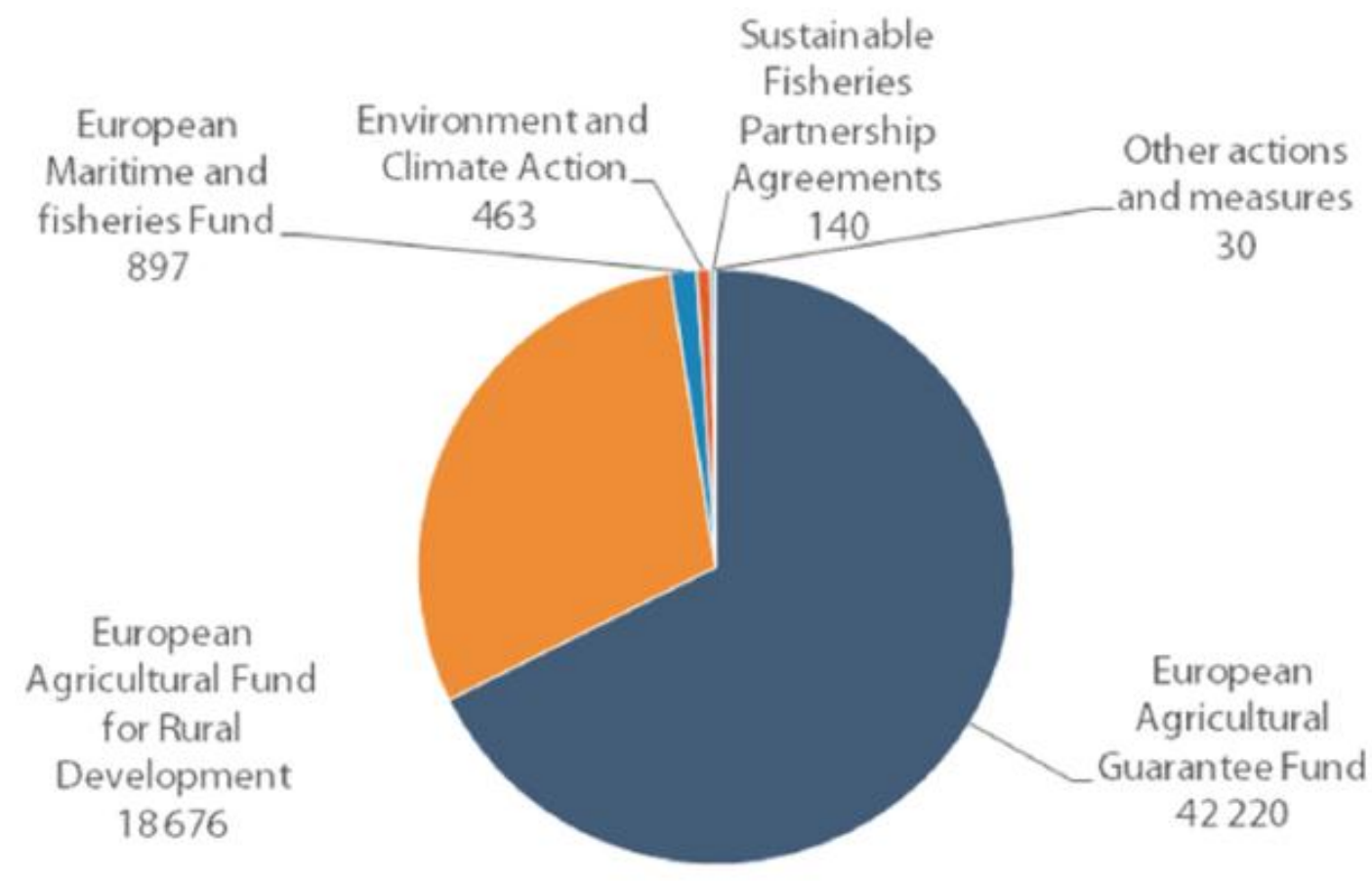

Fig.1. Financing of the European Union for Agricultural Objects

The share of thermal energy in the total energy balance of rural areas is about $90 \%$. A considerable amount of it is spent on the heat supply of the premises of livestock complexes. For example, breeding poultry under industrial conditions is characterized by a large concentration of poultry on the premises and involves the creation of bulky poultry complexes. This necessitates compliance with the special requirements for ensuring the required temperature regime in order to obtain high productivity of poultry at lower specific feed costs per unit of production. 
Analysis of recent research and publications. In Ukraine and abroad researches of systems of heat supply of the industrial complexes, to which the poultry houses belong, have been engaged for a long time. The greatest contribution to the development of theory and practice in this direction was made by scientists: Draganov B.H., Aerts J.M., Berckmans D., Kokorin O.J., Clausen G., Delmote C. etc. In these works, the influence of various factors on the thermal regime of the premises was established. This made it possible to analyze the existing heating systems for cellular retention of poultry [1...7].

The purpose of this publication is to investigate the effectiveness of the heat supply system of a broiler house and propose a new design for improving the energy efficiency of the facility.

The system of heat supply of the house. Due to poor temperature parameters in the poultry house, the potential productivity of the poultry is only $20-30 \%$ of the total productivity. There is an increase in metabolism, accompanied by an increase in feed costs. When breeding poultry meat breeds the deviation of the air temperature from the required value by only one degree leads to a marked decrease in the productivity of the poultry. Therefore, the task of modern systems of heat supply of poultry premises is to maintain the necessary temperature parameters in the habitats of poultry with quality control of air temperature as the poultry grows, which will significantly reduce energy consumption.

Air heating systems with modernized heating and ventilation equipment and automatic equipment are widespread among modern systems of heat supply for broiler houses. Such systems are widely used in Europe.

Air heating system of poultry house (fig. 2) is used both for floor and cellular maintenance of the poultry [2]. The main components of this scheme are exhaust window fans, installation of which is carried out in wall openings along the entire length of the poultry house in the required amount, and also inlet roof fans or inlet mines, if mechanical inlet is not required.

This heating system works according to the scheme "inlet through the roof - exhaust through the window openings". As a result of such a system, the supply air is mixed with 
the pre-heated under the ceiling [3,4]. This ensures a uniform heating of the entire area of the poultry house.

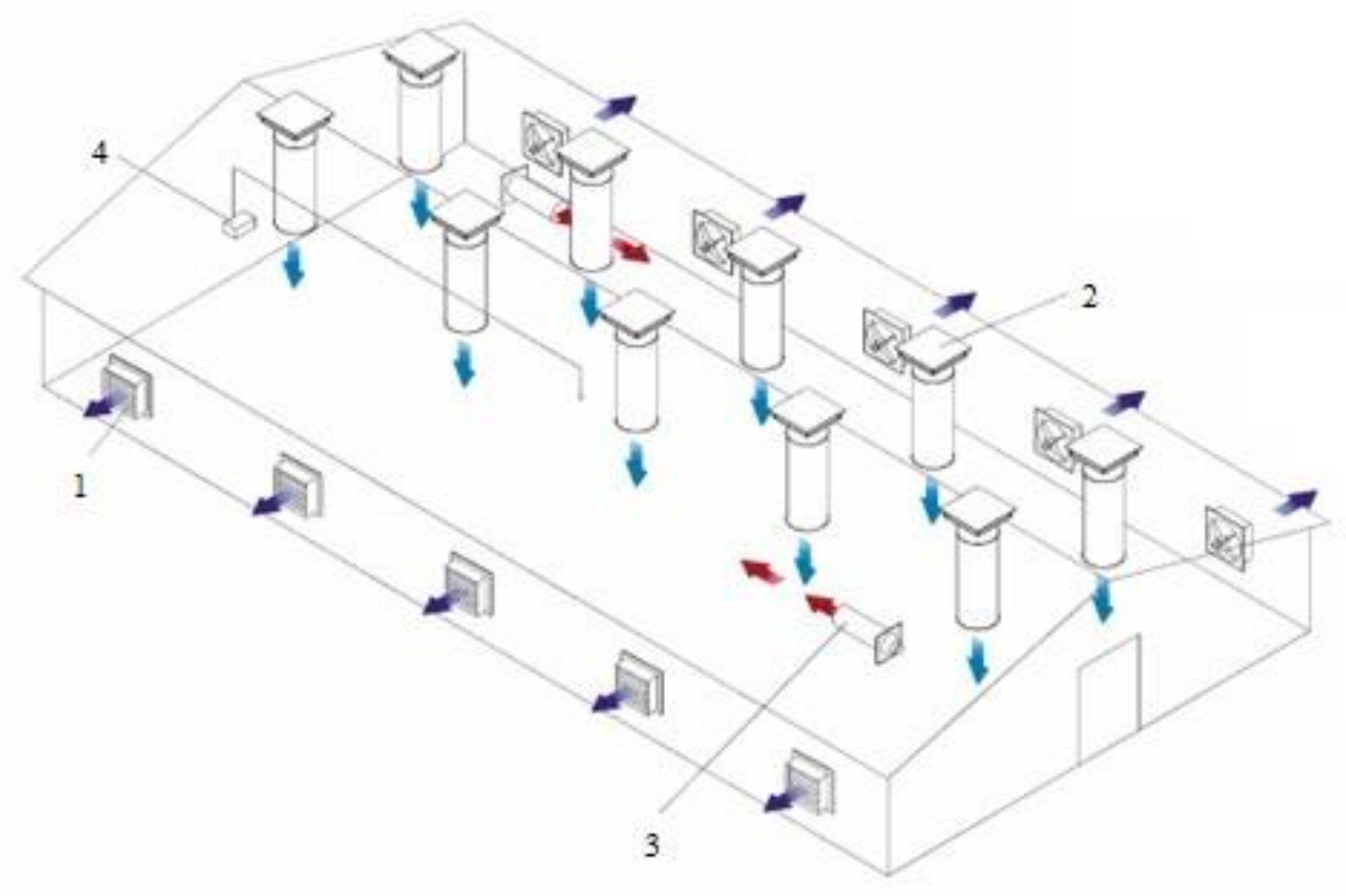

Fig.2. Heating and ventilation system of the poultry house:

1 - exhaust window fan; 2 - inlet roof fan; 3 - air heater; 4 - automatic ventilation control station

Modular way of growing the poultry. The operation of the air heating system is based on providing the required temperature in the room, creating a large air exchange and, as a result, increasing the heat load on the ventilation system. In addition, such a heat supply system contributes to the rapid spread of infection in the poultry house, which is a negative phenomenon when poultry is growing.

Therefore, the design of a local heating system, which is able to provide the necessary zoo hygienic requirements in the habitat of the bird and a new way of growing poultry - modular poultry farming was proposed.

With this method of keeping the poultry, the specified temperature conditions are created and a certain microclimate is required to ensure the zoo hygienic requirements 
with possible efficient and economical use of energy resources during economically justified period of normal operation $[5,6,7]$. The poultry is located in the module from the first day of breading. The technological process of keeping the poultry takes 60 days when breading the young poultry for meat. At the end of the production cycle, the average live weight of broilers is $1.2 \ldots 1.4 \mathrm{~kg}$.

The module is heated by an infrared heater, which will provide the necessary temperature conditions for the broiler from the first days of life. In addition, an infrared heater will create a dynamic microclimate, which will meet the required parameters as the poultry grows. An exhaust outlet is located above the infrared heater, which is designed to remove contaminated air from the module. Also an exhaust outlet will be able to remove the fraction of convective heat from the heater. In the future, this useful heat will be used in the inlet and exhaust ventilation installation for heating the supply air. The supply air goes through the static pressure chamber and the air distributor to the module, thereby ensuring the supply of fresh air evenly at a permissible speed of $0.1-0.3 \mathrm{~m} / \mathrm{s}$ (fig.3).

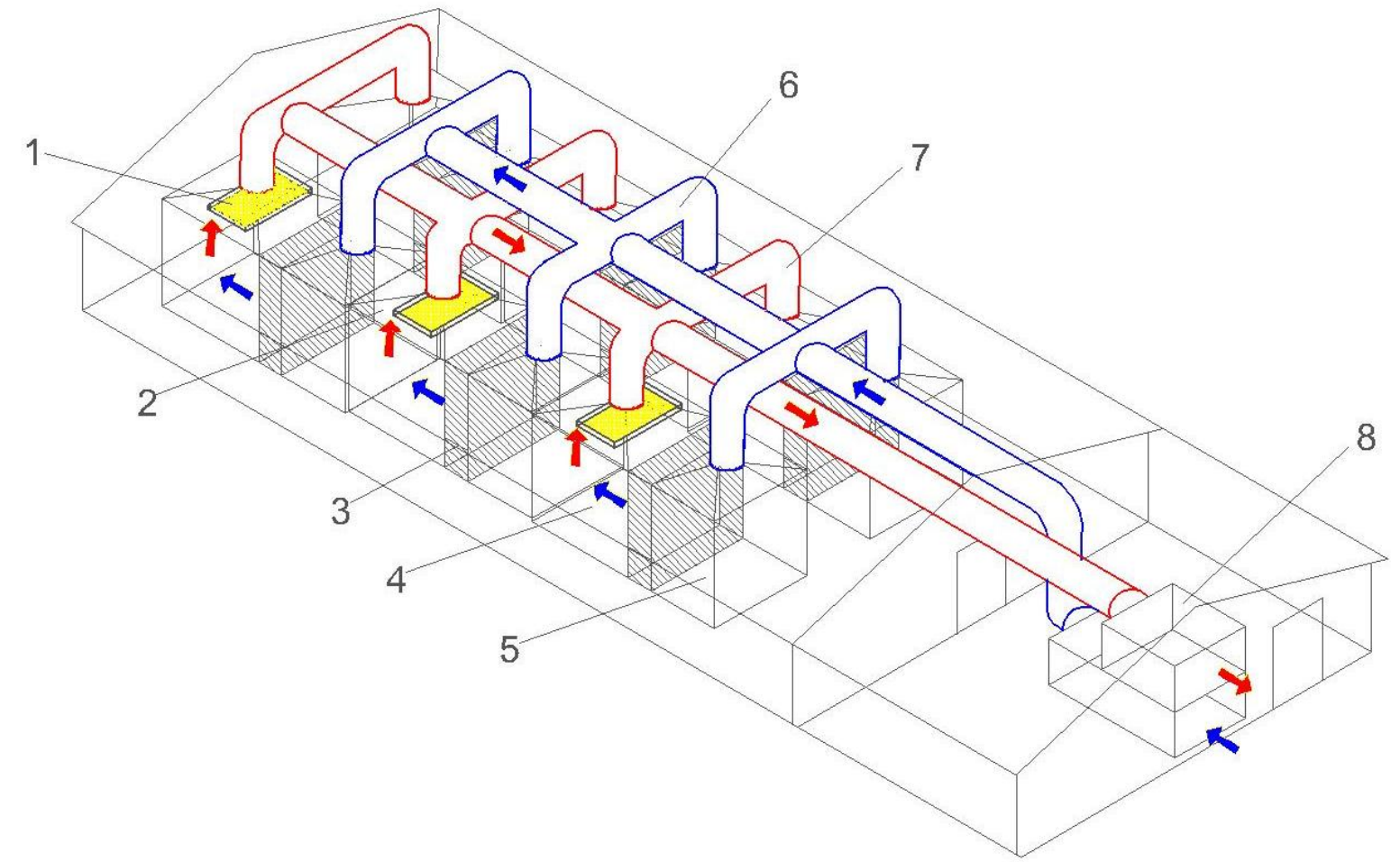

Fig.3. Heating and ventilation system of the poultry house with modular breeding of poultry:

1 - infrared heater; 2 - exhaust outlet; 3 - air distributor; 4 - module for growing poultry; 5 - static pressure chamber; 6 - supply air duct; 7 - exhaust air duct; 8 - ventilation unit 
By using this method of growing it is possible to achieve greater conservation of the livestock of the poultry and increase its weight gain, because the poultry is located in one place throughout the process and moves little. Also, infrared radiation has a positive effect on it well-being, because it provides the necessary zoohygienic conditions directly in the technological area, which is very important in the first days of the poultry's life.

From an economic point of view, when using infrared heaters, energy savings are 40 - 50\%, compared to other heating systems. The use of an exhaust outlet over an infrared heater as an element of the supply and exhaust ventilation system with heat recovery will significantly save energy when heating the supply air.

Investigation of the design of the exhaust outlet. The design of the exhaust outlet with an infrared heater was patented [8]. The scheme of the construction is shown in Fig. 4.
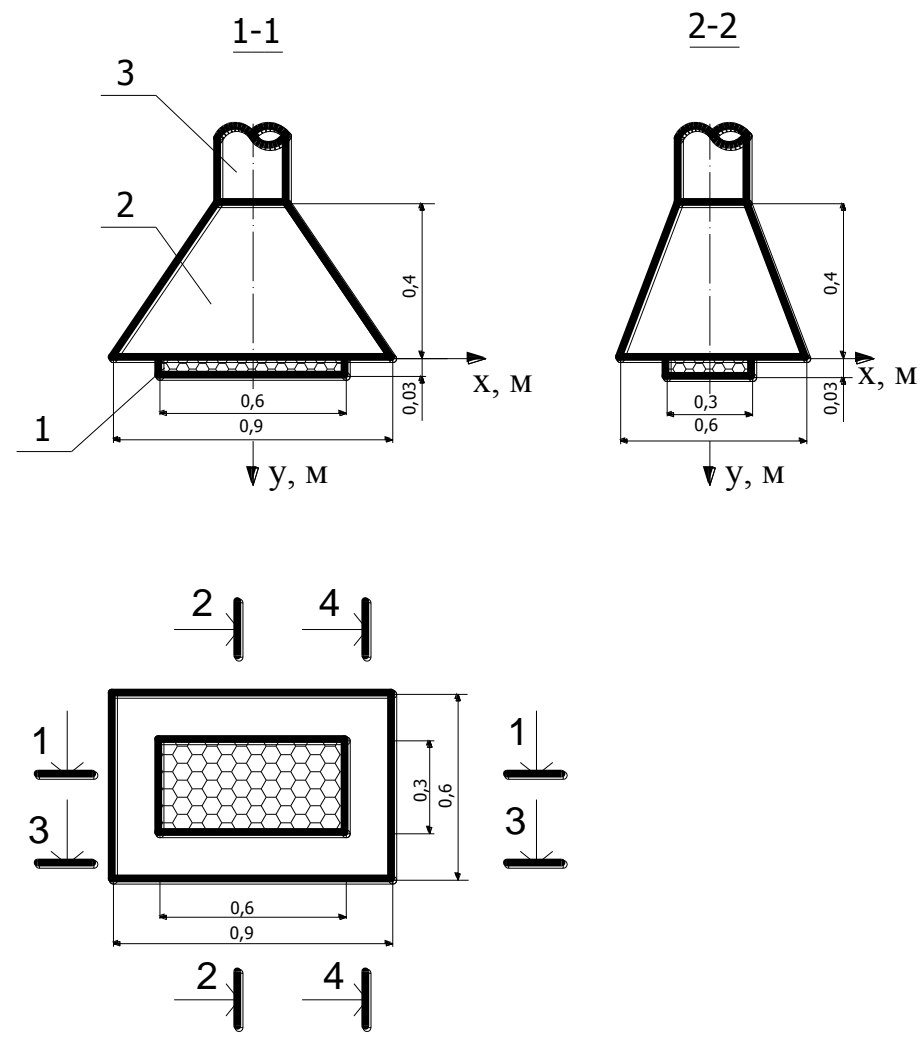

Fig. 4. Design features of an exhaust outlet with an infrared heater: 1 -infrared heater; 2 - exhaust outlet; 3 - exhaust pipe

After switching on the device from the surface of the rectangular ceramic plate infrared heater 1 radiates heat fluxes. Simultaneously with the heating, the polluted air is 
localized and removed from the poultry's stay area by the exhaust outlet 2 through the exhaust pipe 3, which is connected by a duct to the exhaust ventilation system.

The use of the proposed design of an infrared heater with an exhaust umbrella results in more efficient removal of contaminated air, and therefore the amount of heat, by increasing the range of the suction torch. There is a uniform distribution of isolines around the perimeter of the suction hole.

The results of the studies can be represented graphically. The amount of heat removed by the outlet is determined by the heat power $Q_{\text {heater }}, \mathrm{W}$ and the exhaust air flow rate, $L_{\text {out }}, \mathrm{m}^{3} / \mathrm{h}$.

A graphical representation of the results of the experimental studies is shown in Fig. 5.

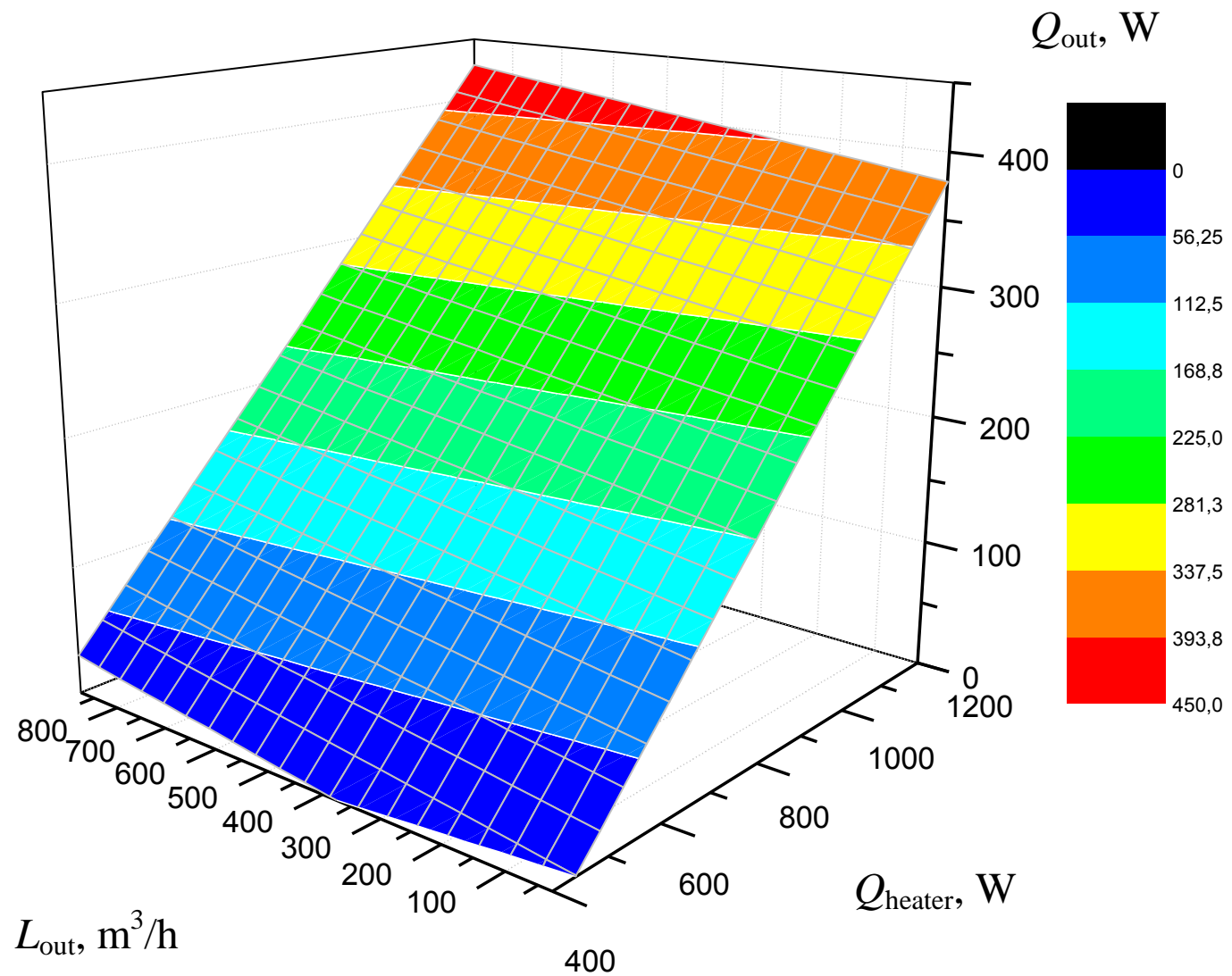

Fig. 5. Dependence of the amount of heat removed $Q_{\text {out }}, \mathrm{W}$ from the heat output of the infrared heater, $Q_{\text {heater }} \mathrm{W}$ and exhaust air consumption $L_{\text {out }} \mathrm{m}^{3} / \mathrm{h}$

The amount of heat removed by the exhaust outlet, $Q_{\text {out }}$, W can be determined depending on the exhaust air flow rate, $L_{\text {out }}, \mathrm{m}^{3} / \mathrm{h}$ at a certain power of the infrared heater 
$Q_{\text {heater }}, \mathrm{W}$. At a thermal power of $400 \mathrm{~W}$, the formula for determining the amount of heat recovered looks like:

$$
Q_{\text {out }}=3.75+0.029 \cdot L_{\text {out }}, \mathrm{W} .
$$

At the thermal power of the heater $800 \mathrm{~W}$ :

$$
Q_{\text {out }}=12.5+0.185 \cdot L_{\text {out }}, \mathrm{W} .
$$

At the thermal power of the heater $1200 \mathrm{~W}$ :

$$
Q_{\text {out }}=0.43 \cdot L_{\text {out }}-0.16, \mathrm{~W} .
$$

The highest amount of heat removed by the exhaust outlet is observed at the maximum thermal power of the radiator and the maximum amount of exhaust air that is at the largest cross-sectional area of the fan nozzle.

The graphical results of the experimental studies can be summarized by obtaining an approximate dependence:

$$
Q_{\text {out }}=187.13+160.38 \frac{Q_{\text {heater }}-800}{400}+21.28 \frac{L_{\text {out }}-790}{90}+18.23 \frac{Q_{\text {heater }}-800}{400} \cdot \frac{L_{\text {out }}-790}{90}
$$

Variation intervals for input factors are used in this dependence: $Q_{\text {out }}$, W at $400 \mathrm{~W} \leq Q_{\text {heater }} \leq 1200 \mathrm{~W}, 700 \mathrm{~m}^{3} / \mathrm{h} \leq L_{\text {out }} \leq 880 \mathrm{~m}^{3} / \mathrm{h}$.

From the above dependence it is seen that the greatest influence on the amount of heat removed by the exhaust outlet has the thermal power of the heater $Q_{\text {heater }}$, W. The "plus" sign near the coefficient indicates that the higher the power of the infrared heater, placed under the exhaust outlet, the greater the amount of heat localized by the outlet. With constant values of exhaust air and an increase in the heat output of the heater from $800 \mathrm{~W}$ to $1200 \mathrm{~W}$, the amount of utilized heat will increase almost twice.

Conclusions and Prospects. The article justifies the feasibility of using energyefficient technologies based on infrared radiation. Efficiency of application of the module for growing poultry with infrared radiator and forced ventilation system was confirmed. The field of influence of the exhaust outlet was studied and investigated under field conditions. It is established that the outlet operation does not affect the overall distribution of air flow in the module, since the radius of the suction torch is $0.16 \mathrm{~m}$ with a maximum 
exhaust air flow rate of $880 \mathrm{~m}^{3} / \mathrm{h}$. Based on studies conducted on the efficiency of the exhaust umbrella, it is found that the amount of heat recovered from the exhaust air is $30 \%$ of the heat output of the infrared heater.

\section{Список літератури}

1. How The EU Budget Is Spent: Common Agricultural Policy. European Commission, DG Budget. Members' Research Service. July 20. 2016.

2. Clausen G. Ventilation, good indoor air quality and rational use of energy / G. Clausen, C. Delmote // Urban Air, Indoor Environment \& Human Exposure. European collaborative action. Report nr 23, Eur. 2003. 95 p.

3. Piotrowski J. The Application of Chromatography Method in the Research into Infiltration Heat Losses / J. Piotrowski, L. Faryniak. Institute of Heating and Ventilating Warsaw University of Technology. Warsaw. 1994. P. 111-114.

4. CEN draft standard prEN 13779. Ventilation for buildings. Perfomance requirements for ventilation and air-conditioning systems. CEN Technical committee 156. Working group 7. Draft, CEN. Brussels. 2001.

5. ДБН В.1.2-11-2008. Основні вимоги до будівель і споруд. Економія енергії: Державні будівельні норми України. Київ: Мінрегіонбуд України, 2008. 12 с.

6. Aerts J. M., Berckmans D. Virtual Chicken for Climate Control design: Static and Dynamic Simulations of Heat Losses A Transactions of the ASAE, 2004. Vol. 47, no. 5. P. $1765-1772$.

7. Conserving energy with infrared heating. Plant Eng. Barrington, Ill. United States: Journal, v. 31, nr 8, 1977. P. 155 - 156.

8. Патент України на корисну модель №32437. Нагрівальний пристрій для пташників / Желих В.М., Сподинюк Н.А. // Заявка 12.05.2008. Опубл. 12.05.2008. Бюл. №9.

\section{References}

1. How The EU Budget Is Spent (2016). Common Agricultural Policy. European Commission. DG Budget. Members' Research Service]. July 20.

2. Clausen G., Delmote C. (2003). Ventilation, good indoor air quality and rational use of energy. Urban Air, Indoor Environment \& Human Exposure. European collaborative action]. Report nr 23, Eur. 95.

3. Piotrowski J., Faryniak L. (1994). The Application of Chromatography Method in the Research into Infiltration Heat Losses. Institute of Heating and Ventilating Warsaw University of Technology. Warsaw. $111-114$.

4. CEN draft standard prEN 13779 (2001). Ventilation for buildings. Perfomance requirements for ventilation and air-conditioning systems. CEN Technical committee 156. Working group 7, Draft, CEN. Brussels.

5. DBN V.1.2-11-2008. (2008). Osnovni vymohy do budivel i sporud. Ekonomiia enerhii: Derzhavni budivelni normy Ukrainy]. Kyiv: Minrehionbud Ukrainy, 12. 
6. Aerts, J.M., Berckmans, D. (2004). A Virtual Chicken for Climate Control design: Static and Dynamic Simulations of Heat Losses. Transactions of the ASAE, 47 (5), 1765 1772.

7. Conserving energy with infrared heating. (1977). Plant Eng. Barrington, Ill. United States: Journal, 31 (8), 155 - 156.

8. Zhelykh, V. M., Spodyniuk, N. A. (2008). Nahrivalnyi prystrii dlia ptashnykiv [Patent Ukrainy na korysnu model №32437. 12.05.2008]. No. 9.

\section{ЗАСТОСУВАННЯ ЕНЕРГОЕФЕКТИВНИХ ОПАЛЮВАЛЬНИХ СИСТЕМ В ПТАШНИКАХ}

\section{Н. А. Сподинюк}

Анотація. Частка теплової енергї в загальному енергетичному балансі сільської місиевості становить близько $90 \%$. Значна ї̈ частина витрачається на теплопостачання приміщень тваринницьких комплексів. Наприклад, розведення птиці в промислових умовах характеризується великою концентрацією ї̈ в приміщеннях і передбачає створення об'ємних пташиних комплексів. Це зумовлює дотримання спеціальних вимог щодо забезпечення необхідного температурного режиму з метою отримання високої продуктивності птиці при менших питомих витратах кормів на одиницю продукиії. Через погані температурні показники в пташнику потениійна продуктивність птииі становить лише 20-30 \% від загальної продуктивності. Відбувається збільшення метаболізму, що супроводжується збільшенням витрати кормів. При розведенні м'ясних порід птиці відхилення температури повітря від необхідного значення лише на один градус призводить до помітного зниження продуктивності птиці. Тому завданням сучасних систем теплопостачання приміщень пташників є підтримка необхідних температурних параметрів у розташуванні птиці з контролем якості температури повітря при зростанні птиці, щуо значно зменшить споживання енергії. Запропоновано розроблення локальної системи опалення, яка здатна забезпечити необхідні гігієнічні вимоги щодо розташування птичі та новий спосіб вирощування птиџі модульне вирощування. При такому способі утримання птиці забезпечуються необхідні температурні умови і необхідний певний мікроклімат для забезпечення зоогігієнічних вимог з можсливим ефективним та економічним використанням енергоресурсів протягом економічно обтрунтованого періоду нормальної експлуатаиіi. У роботі обгрунтовується можливість використання енергоефективних технологій на основі інфрачервоного випромінювання. Підтверджено ефективність застосування модуля для вирощування птиці 3 інфрачервоним опаленням та системою примусової вентиляиї. Поле впливу випускного отвору було вивчено та досліджено в натурних умовах. Встановлено, щзо робота випускного отвору не впливає на загальний розподіл повітряного потоку в модулі, оскільки радіус всмоктувального факела становить 0,16 м при максимальній швидкості потоку відпраџьованого повітря $880 \mathrm{~m}^{3} / 2 о д$. На підставі проведених досліджень щцодо ефективності випускного отвору, встановлено, щуо 
"Енергетика і автоматика", №4, 2019 р.

кількість відведеного тепла з відпрацуьованого повітря становить $30 \%$ тепловіддачі інфрачервоного нагрівача.

\section{Ключові слова: інфрачервоний нагрівач, випускний отвір, витяэнний зонт, модуль для вирощування птиці}

\section{ПРИМЕНЕНИЕ ЭНЕРГОЭФФЕКТИВНЫХ ОТОПИТЕЛЬНЫХ СИСТЕМ В ПТИЧНИКЕ}

\section{Н. А. Сподинюк}

Аннотация. Доля тепловой энергии в общем энергетическом балансе сельской местности составляет около 90 \%. Часть ее расходуется на теплоснабжение помещцений животноводческих комплексов. Например, разведение птиць в промышленных условиях характеризуется большой конщентрацией ее в помещуениях и предусматривает создание объемных птичьих комплексов. Это приводит к соблюдению специальных требований по обеспечению необходимого температурного режима с целью получения высокой продуктивности птиць при меньших удельных затратах кормов на единицу продукции. Из-за плохих температурных показателей в птичнике потенциальная продуктивность птиць составляет лишь 20-30\% от общей производительности. Ускорение метаболизма сопровождается увеличением затрат кормов. При разведении мясных пород птицы отклонения температуры воздуха от требуемого значения только на один градус приводит к заметному снижению продуктивности птицьь. Поэтому задачей современных систем теплоснабжения помещуений птичников является поддержка необходимых температурных параметров в расположении птицы с контролем качества температуры воздуха по мере роста птицы, что значительно уменьшит потребление энергии. Предложена разработка локальной системь отопления, которая способна обеспечить необходимые гигиенические требования по размещзению птицьы и новый способ выращуивания птиц̧ы - модульное выращзвание. При таком способе содержания птицыь обеспечиваются необходимые температурные условия и необходим определенный микроклимат для обеспечения зоогигиенических требований с возможным эффективным и экономичным использованием энергоресурсов в течении экономически обоснованного периода нормальной эксплуатации. В работе обосновывается возможность использования энергоэффективных технологий на основе инфракрасного излучения. Подтверждена эффективность применения модуля для выращчивания птицьы с инфракрасным отоплением и системой принудительной вентиляции. Поля влияния выпускного отверстия были изучены $и$ исследованы в натурных условиях. Установлено, что работа выпускного отверстия не влияет на общее распределение воздушного потока в модуле, поскольку радиус всасывающего факела составляет 0,16 м при максимальной скорости потока отработанного воздуха $880 \mathrm{~m}^{3} / 4 а с . ~ Н а$ основании проведенных исследований по эффективности выпускного отверстия, установлено, что количество отведенного тепла из отработанного воздуха составляет 30 \% теплоотдачи инфракрасного обогревателя. 
"Енергетика і автоматика", №4, 2019 р.

Ключевые слова: инфракрасный обогреватель, выпускное отверстие, вытяжнной зонт, модуль для выращиввания птицы 